Gelanggang Pendidikan Jasmani Indonesia

\title{
PERBEDAAN PENGARUH GAYA MENGAJAR KOMANDO DENGAN LATIHAN TERHADAP MINAT PESERTA DIDIK PADA PEMBELAJARAN PERMAINAN BOLA VOLI KELAS X MADRASAH
}

\author{
Hendi Buwana Putra ${ }^{1}$, Asim ${ }^{2}$, Eko Hariyanto ${ }^{3}$ \\ Universitas Negeri Malang, Jalan Semarang 5 Malang
}

\begin{abstract}
Info Artikel
Sejarah Artikel:

Diterima September 2017

Disetujui Oktober 2017

Dipublikasikan Desember 2017

Keywords:

gaya mengajar komando, gaya mengajar latihan, minat belajar siswa.

Abstrak

Permainan bolavoli merupakan salah satu permainan bola besar yang menjadi materi ajar di sekolah dalam mata pelajaran pendidikan jasmani dan kesehatan. Tujuan dar penelitian ini untuk mengetahui perbedaan pengaruh gaya mengajar komando dengan gaya mengajar latihan terhadap minat belajar siswa kelas X MAN Batu. Penelitian ini adalah jenis penelitian eksperimental sungguhan dan pengumpulan data menggunakan teknik angket dan dokumentasi. Dari hasil analisis varian satu jalur (one way anava). Ditemukan bahwa gaya mengajar komando berpengaruh signifikan terhadap minat belajar peserta didik. Gaya mengajar latihan berpengaruh signifikan terhadap minat peserta didik. Terdapat perbedaan pengaruh gaya mengajar komando dan latihan. Disarankan agar memilih gaya mengajar latihan.

\section{Abstract}

Volleyball game is one big ball game which became teaching materials in school in the subjects of physical education and health. The purpose of the research is find out the different influence of command teaching styles with practice teaching styles toward learning interest student in the class X MAN Batu City. This research is a kind of true experimental research and data collection using questionnaires and documentation techniques. From the analysis of variance single-lane (one way ANOVA). It was found that the teaching style command significant effect on the interest of learners. This style of teaching practice significant influence on the interest of learners. There are differences in the effect of teaching style command and practice. Choose suggestion is practice taching style.
\end{abstract}

(C) 2017 Universitas Negeri Malang

\footnotetext{
Alamat korespondensi:

E-mail: hendibuwanaputra999@gmail.com
}

ISSN 0853-5043 (cetak)

\section{PENDAHULUAN}

Salah satu aspek pendidikan yang utama pada sistem kurikulum adalah pendidikan jasmani. Pendidikan jasmani membentuk kebugaran jasmani, sikap dan karakter dari peserta didik. "Pendidikan jasmani bertujuan untuk mengembangkan aspek kebugaran jasmaniah, keterampilan sosial, stabilitas emosional, tindakan moral, penalaran dan pengenalan lingkungan melalui aktifitas jasmani yang direncanakan secara sistematis" (Arisandi, 2009:14). Tujuan pendidikan jasmani dan kesehatan adalah untuk memperbaiki standar kesehatan melalui pendidikan yang terpadu.

Pendidikan yang terpadu dapat didukung dengan proses pembelajaran yang 
baik dan kondusif. Pembelajaran adalah proses interaksi peserta didik dengan pendidik dan sumber belajar pada suatu lingkungan belajar. Nurruddin (2010:13) berpendapat "proses pembelajaran yang dulu kita kenal sebagai proses belajar mengajar adalah interaksi antara perilaku guru dan perilaku peserta didik". Pembelajaran merupakan bantuan yang diberikan pendidik agar dapat terjadi proses perolehan ilmu dan pengetahuan, penguasaan kemahiran dan sifat, serta pembentukan sikap dan kepercayaan pada peserta didik.

Proses pembelajaran pada hakikatnya merupakan interaksi antara dua unsur manusiawi yakni peserta didik dan guru. "Interaksi guru dan peserta didik selalu mencerminkan perilaku pengajaran tertentu, perilaku pembelajaran tertentu dan sekumpulan tujuan tertentu yang akan dicapai" (Moston dalam Asim, 2013:15). Dalam interaksi tersebut, peserta didik lebih sebagai subjek pokok bukan objek belajar yang selalau dibatasi dan diatur oleh guru. Sebagai subjek dalam pembelajaran, peserta didik diharuskan aktif agar dapat belajar sesuai dengan bakat dan segala potensi yang dimiliki peserta didik. Husdarta dan Saputra (2013:1) berpendapat bahwa "kegiatan belajar dilakukan oleh peserta didik, dan melalui kegiatan itu akan ada perubahan perilakunya, sementara kegiatan pembelajaran dilakukan oleh guru untuk memfasilitasi proses belajar". dapat disimpulkan bahwa pembelajaran merupakan proses interaksi antara guru dan siswa yang dilaksanakan pada suatu lingkungan belajar dan didukung dengan materi ajar untuk mencapai tujuan ilmu pengetahuan yang diinginkan. Juga dapat dikatakan suatu rangkaian proses belajar individu untuk mencapai pengetahuan yang diinginkan.

Gaya mengajar merupakan suatu cara pilihan guru dalam pemberian materi ajar yang akan dilakukan untuk memberi kemudahan dalam penguasaan tugas ajar. Gaya mengajar adalah suatu cara yang diterapkan untuk memproses atau mengolah pembelajaran untuk mencapai interaksi guru dan peserta didik yang baik. Rukmana (2008:4) berpendapat bahwa "gaya mengajar merupakan siasat untuk menggiatkan dalam menggiatkan tugas-tugas ajar". Rancangan pada pembelajaran sering mengacu pada bagaimana cara atau gaya guru dalam memberikan pengajaran. Nuruddin (2010:13) "pola-pola keputusan disebut gaya mengajar (teaching style), sedangkan kerangka kerja yang menopang gaya-gaya mengajar disebut rancangan gaya mengajar". Setiap tindakan dari kegiatan mengajar yang direncanakan menciptakan lingkungan belajar yang ideal. Dengan lingkungan belajar yang ideal maka pembelajaran akan berjalan sesuai dengan yang sudah direncanakan guru.

Dari pendapat beberapa ahli tersebut dapat disimpulkan bahwa gaya mengajar adalah cara guru memberikan materi ajar kepada peserta didik dengan metode dan model pembelajaran yang mempunyai ciri-ciri khusus. Gaya mengajar juga dapat diartikan ciri khusus dari suatu pembelajaran yang telah diterapkan guru pendidikan. Ciri khusus dari guru adalah dalam membuat lingkungan belajar yang berbeda-beda pada setiap pembelajaran dan tahap-tahap yang dirancang dalam pembelajaran.

Uraian gaya mengajar menggambarkan bahwa setiap gaya mengajar terdapat tujuan dan hakikat yang mendasarinya. Hakikat setiap gaya mengajar mengidentifikasikan bahwa penerapan pada gaya mengajar yang diberikan sangatlah fleksibel terhadap kesulitan pada setiap gaya. "Perencanaan mengajar dapat dilihat dari anatomi gaya mengajar. Gaya mengajar mengidentifikasi dan diorganisasikan dalam tiga tahap, yaitu tahap pra pertemuan, tahap pertemuan dan tahap pasca pertemuan" (Nuruddin, 2010:16). Ciri dari gaya mengajar yang dikenalkan oleh Mosston adalah pemberian tugas dan tanggung jawab baik guru maupun peserta didik pada setiap episode preimpact-set, impact-set, dan post-impact-set (Asim, 2013:19). Setiap gaya mengajar memiliki karakteristik masing-masing dalam pembagian tugas dan tanggung jawab pada setiap episode. $\mathrm{Hal}$ ini memungkinkan guru untuk memilih metode yang tepat dalam pembelajaran. Hakikat tersebut memberikan gambaran yang jelas pada setiap gaya. Ketika guru menjadi ahli dalam menggunakan setiap gaya tersebut, guru akan lebih fleksibel dan mampu mengubah gaya tersebut, sehingga mencapai lebih banyak tujuan dan mendapatkan lebih banyak peserta didik yang berhasil dalam mencapai pembelajaran yang diinginkan.

Ada sebelas macam gaya mengajar dalam pendidikan jasmani diantaranya: (1) komando /command, (2) latihan/practice, (3) resiprocal/resiprocal, (4) koreksi diri/ selfcheck, (5) inklusi/inclusion (6) penemuan terbimbing/guded discovery (7) penemuan tunggal/ convergen discovery (8) penemuan beragam/ divergent production (9) program indivi$\mathrm{du} /$ individual program (10) inisiasi peserta didik/learner initiated, dan (11) pengajaran mandiri/self teaching. Pemilihan gaya mengajar tersebut disesuaikan dengan situasi dan kondisi lingkungan. Peserta didik lebih sebagai subjek 
pokok bukan objek belajar yang selalau dibatasi dan diatur oleh guru. Sebagai subjek dalam pembelajaran, peserta didik diharuskan aktif agar dapat belajar sesuai dengan bakat dan segala potensi yang dimiliki peserta didik. Keaktifan peserta didik dapat diwujudkan baik keaktifan secara fisik maupun keaktifan mental. Pembelajarn yang menekankan pada pendekatan pada peserta didik merupakan salah satu sistem pembelajaran yang diyakini mampu menjawab tantangan masa depan.

Gaya mengajar komando adalah salah satu tipe gaya mengajar yang dijelaskan oleh mosston . Menurut Husdarta (2013:31) "gaya ini bertujuan mengenalkan pada peserta didik untuk melakukan tugas gerak secara akurat dan di dalam waktu yang singkat peserta didik harus mengikuti segala intruksi yang disampaikan oleh guru". Gaya mengajar komando yaitu "gaya mengajar yang merupakan gaya mengajar pertama pada spektrum digolongkan oleh guru yang membuat semua keputusan pada anatomi dari suatu gaya mengajar" (Asim, 2013:32). Peran guru adalah membuat semua keputusan pada tahap pre impact,tahap impact dan post impact. Sedangkan peran peserta didik adalah pratek dan mengikuti. Inti dari gaya mengajar komando adalah hubungan yang langsung dan cepat antara stimulus dari guru mendahului gerakan dari setiap pembelajaran. "Ciri khas dari gaya mengajar komando adalah guru yang selalu memberikan sinyal" (Asim, 2013:33). Seorang guru yang berharap untuk menggu-nakan gaya mengajar ini harus sepenuhnya mengetahui struktur keputusan (anatomi dari gaya mengajar ini), urutan keputusan, hubu-ngan yang mungkin antara sinyal perintah dan respon yang di harapakan, kelayakan suatu tugas dan kemampuan yang dimiliki oleh peserta didik saat ini.

Gaya mengajar komando guru berhak membuat semua keputusan. Pertama adalah keputusan yang dibuat pada tahap pre impact adalah untuk merancang suatu interaksi antara guru dan peserta didik. Pada tahap ini peran guru adalah untuk membuat keputusan menyangkut kategori-kategori yang telah ditentukan. Kategori ini merupakan uraian tentang isi rancana pengajaran. Kedua adalah keputusan yang dibuat pada tahap impact yaitu pada tahap pelaksanaan. Tujuan yang dibuat pada tahap impact adalah untuk mengajak para peserta didik agar aktif berpartisipasi dan meneruskan apa yang sudah dilaksanakan/diputuskan pada tahap pre impact. Oleh karena itu seorang guru harus membuat suatu urutan keputusan guna menyusun adegan bagi suatu episode dalam gaya mengajar komando. Ketiga adalah keputusan yang dibuat pada tahap post impact menawarkan umpan balik pada peserta didik dalam hal pengerjaan tugastugas dan peranan peserta didik dalam mengikuti keputusan guru. "Peran guru adalah membuat semua keputusan pada tahap pre impact, tahap impact dan post impact" (Asim, 2013:32).

Dapat disimpulkan bahwa gaya mengajar komando adalah suatu gaya mengajar yang berfokus pada bakat atau kemampuan guru pendidikan jasmani dalam mengolah pembelajarn. Pembelajaran dibuat dan dirancang dengan guru berperan penuh dalam mengambil alih semua tahap-tahap dalam pembelajaran. Dalam tahap ini pencapaian tujuan pembelajaran tergantung dari bagaimana kemampuan guru mengkondisikan proses pembelajaran pada tahap pre impact, impact dan post impact. Ciri khas dari gaya mengajar ini adalah sinyalsinyal dari guru pendidikan jasmani dalam mengendalikan peserta didik dan memberikan materi ajar.

Gaya mengajar latihan adalah tipe gaya mengajar ke dua. Gaya mengajar ini mempunyai pembagian tugas antara pengajar dan peserta didik. Peran guru adalah membuat semua keputusan pada tahap pre impact dan tahap post impact. Pada tahap impact. Guru memberikan kesempatan pada peserta didik untuk menentukan bagaimana berlangsung pembelajaran pada tahap impact sedangkan peserta didik memiliki kesempatan untuk mempelajari bagaimana membuat keputusan pada tahap impact di dalam parameter yang telah ditentukan oleh guru. Dalam gaya mengajar ini yang paling diutamakan adalah kepercayaan antara pengajar dan peserta didik. Asim (2013:55) berpendapat bahwa "guru belajar untuk mempercayai peserta didik dalam membuat keputusan yang sesuai pada saat mengerjakan tugas dan peserta didik belajar bagaimana membuat keputusan secara sengaja dan bebas dalam hubungannya dengan pengerjaan tugas". Sedangkan menurut Husdarta (2013:32) "tujuan dari gaya latihan adalah menawarkan kepada peserta didik waktu untuk melakukan latihan secara individu atau privat. Juga guru memberikan umpan balik secara individu dan privat".

Dari pendapat beberapa ahli tersebut dapat ditarik kesimpulan bahwa gaya mengajar latihan adalah gaya mengajar yang memfokuskan tahap inti pembelajaran kepada peserta didik. Artinya gaya mengajar ini mengajarkan kemandirian kepada peserta didik untuk mengambil Sembilan keputusan dalam 
tahap inti pembelajaran. Sembilan keputusan tersebut meliputi sikap, lokasi, urutan tugas, waktu dimulai pengerjaan setiap tugas, langkah dan ritme, waktu berhenti setiap tugas, interval, pakaian dan penampilan, pertanyaan awal untuk klarifikasi. Jadi peserta didik dituntut mandiri dan bertanggung jawab atas keputusan yang sudah diambi dan keputusan tersebut nantinya juga akan menyangkut nilai dari peserta didik.

Ada beberapa materi ajar yang ada dipendidikan tingkat sekolah menengah atas adalah permainan bolavoli. Dalam olahraga beregu ini diperlukan kekompakan sebuah regu bolavoli dan pematangan teknik dasar permainan. Menurut Suhadi (2005:3) "permainan bolavoli merupakan permainan beregu dengan tujuan melewatkan bola secara teratur melalui atas net dan mencegah bola menyentuh lantai atau lapangan".

Pembelajaran permainan bolavoli yang terpenting adalah menguasai teknik dasar terlebih dahulu baru bisa meneruskan untuk teknik lanjutan. Beberapa ahli berpendapat teknik dasar sangatlah penting untuk dikuasai terlebih dahulu untuk mencapai permainan bolavoli yang baik. Ahmadi (2007:20) menguraikan "teknik-teknik dalam permainan bolavoli terdiri atas servis, passing bawah, passing atas, block dan smash". Dalam dunia pendidikan tidak diutamakan kemahiran penguasaan teknik dasar permainan bolavoli pada peserta didik, namun guru dituntut untuk mengajarkan pada peserta didik pembelajaran yang benar dan dapat menarik minat peserta didik dengan pembelajaran tersebut. Menurut Durrwachter (1982:3) "permainan bolavoli bisa dipelajari dengan mudah serta banyak mengandung variasi gerak. Dengannya anak didik tidak perlu lama-lama melakukan latihan persiapan sebelum permainan dilangsungkan".

Dari berbagai pendapat tersebut dapat disimpulkan bahwa permainan bolavoli adalah salah satu permainan bola besar yang dimainkan oleh 6 orang pemain pada masingmasing kelompok. Dalam permainan ini bola dimainkan dengan menggunakan tangan. Antara kedua wilayah lapangan dibatasi dengan sebuah net. Ada beberapa teknik dasar dalam permainan bolavoli yaitu passing, servis, block dan smash. Dalam dunia pendidikan peserta didik tidak diharuskan menguasai teknik dasar permainan bolavoli tersebut. Tetapi mempunyai hak untuk mempelajari permainan bolavoli lewat pembelajaran yang telah terorganisir.

Dalam dunia pembelajaran salah satu faktor yang mendukung peserta didik dalam belajar adalah minat. Peserta didik yang memiliki minat belajar maka akan bersungguhsungguh dalam mengikuti pembelajaran. Jika peserta didik bisa mengikuti pembelajaran dengan antusias maka pembelajaran akan berlangsung dengan lancar dan dapat mencapai tujuan yang diinginkan. "Minat besar pengaruhnya terhadap belajar, karena bila bahan pelajaran yang dipelajari tidak sesuai dengan minat peserta didik, peserta didik tidak akan belajar dengan sebaik-baiknya, karena tidak ada daya tarik baginya" (Slameto, 2010:57). Dalam dunia pendidikan sangatlah penting pengendalian minat peserta didik karena jika tidak ada minat dalam belajar maka proses pembelajaran akan terasa sulit. Erat kaitanya dengan hasil belajar minat juga sebagai acuan hasil belajar peserta didik. Minat juga di fungsikan sebagai penumbuh motivasi atau pendorong bagi individu dalam melakukan sesuatu. Hurlock (1980:167) berpendapat bahwa "Minat dapat dan memang berfungsi sebagai tenaga pendorong yang kuat". Pada hakekatnya minat adalah ketertarikan pada suatu hal tanpa ada paksaan dari pihak manapun. Tumbuhnya minat pada diri seseorang akan menjadikan orang tersebut lebih focus pada apa yang akan dia kerjakan. "Minat adalah kecenderungan yang tetap untuk memperhatikan dan mengenang beberapa kegiatan. Kegiatan yang diminati seseorang, diperhatikan terus menerus yang disertai rasa senang" (Slameto. 2010:57). Minat merupakan hal yang sangat penting untuk mencapai tujuan pembelajaran karena semua berawal dari minat belajar peserta didik. Jika terdapat siswa yang kurang berminat dalam belajar munkin dikarenakan model pembelajaran yang diterapkan kurang menarik dan belum menimbulkan rasa senang.

Dalam dunia olahraga tumbuhnya minat berbeda dengan ilmu sosial lainya menurut sejarah dalam olahraga tumbuhnya minat dipengaruhi oleh seberapa besar dampak olahraga tersebut terhadap individu yang melakukanya yang mengakibatkan olahraga tersebut terlihat menarik atau tidaknya. "Dahulu di Yunani olahraga mengacu pada mitologi dan agama. Olahraga difokuskan pada minat remaja pria dari kalangan masyarakat terpandang" (Husdarta, 2011:92). Berdasarkan teori tersebut minat dalam olahraga erat halnya dengan siapa yang melakukan dan olahrga apa yang dilakukan. Ketika olahraga tersebut dimainkan oleh orang terpandang dan olahraga tersebut memberikan dampak popularitas maka olahraga tersebut akan menjadi pilihan. 
Dewasa ini proses pembelajaran semakin monoton atau kurang berkembang sedangkan minat peserta didik terus berkembang. Ini menjadikan peserta didik kurang memperhatikan pada proses pembelajaran karena pada masa remaja peserta didik perlu mengeksplor dirinya tanpa batasan dari seorang pengawas atau guru. Hurlock (1980:214) menyatakan bahwa "Dengan berlangsungnya masa remaja, terdapat perubahan pada beberapa pengelompokan sosial ini. Minat terhadap kelompok yang terorganisir yang kegiatanya direncanakan dan diawasi oleh orang dewasa, dengan cepat menurun karena remaja cenderung tidak suka diperintah".

Dari berbagai deskripsi ahli tentang minat maka dapat ditarik kesimpulan minat adalah ketertarikan individu pada suatu hal yang menyenagkan dan membuat individu tersebut nyaman dan menimbulkan keinginan untuk mengulanginya kembali. Seseorang akan tumbuh minat bila sesuatu yang di inginkanya tercapai dengan jalan yang menyenangkan.

Pada gaya mengajar komando berkembangnya minat peserta didik tergantung pada guru, karena pada gaya ini guru dituntut berpikir kreatif menciptakan suasana kelas yang menarik minat peserta didik. Lingkungan kelas yang tercipta tergantung dengan apa yang dirancang dan dikonsepkan guru sebelumnya. Kuncinya pada kemampuan guru merancang pembelajaran yang menarik dan pengaplikasian yang baik dengan sinyal-sinyal perintah dari guru pada saat pembelajaran berlangsung. Ketika pembelajaran berlangsung seperti yang diinginkan guru maka peserta didik akan tumbuh ketertarikan dan minatnya akan pembelajaran akan terus berkembang. "Seorang siswa misalnya, akan lebih menikmati aktifitasaktifitas pada gaya mengajar komando Semuanya menggambarkan perilaku peniruan" (Asim, 2013:42).

Pada gaya mengajar latihan memberikan suasana kelas yang berbeda, karena pada gaya ini peserta didik dituntut untuk mandiri dalam melaksanakan proses belajar mengajar. Lingkungan dan suasana kelas yang tercipta tergantung kertas tugas yang dirancang guru dan minat peserta didik untuk melaksanakan pembelajaran dengan gaya ini. Peserta didik dituntut mandiri dan bertanggungjawab atas diri sendiri. Minat akan tumbuh bersamaan dengan rasa kemandirian dalam melaksanakan pembelajaran. "Gaya latihan ini merupakan proses berfikir dan lingkungan yang efektif mengajar siswa secara cepat dengan melihat penampilan dan tanggung jawab" (Asim, 2013:67).
Dari hasil observasi di lapangan berdasarkan wawancara dan pengamatan dengan guru pendidikan jasmani MAN Kota Batu dan juga pembagian angket kepada peserta didik berjumlah 50 yang diambil acak dari seluruh kelas X dapat diketahui 22\% peserta didik mengatakan bahwa guru telah memberikan pelajaran secara kreatif, $42 \%$ peserta didik mengatakan kadang-kadang, 36\% peserta didik mengatakan tidak pernah dan diketahui $100 \%$ peserta didik tidak mengetahui dan belum pernah mengenal gaya mengajar komando dan latihan. Berangkat dari analisis kebutuhan dan latar belakang masalah yang dikaji peneliti, maka dapat disimpulkan perlu adanya varisi gaya mengajar bagi guru dalam pembelajaran untuk peserta didiknya agar minat peserta didik dapat tumbuh dan berkembang dengan tujuan pembelajaran yang tercapai maksimal khususnya pada pembelajaran teknik dasar permainan bolavoli kelas X di MAN Kota Batu. Dari permasalahan tersebut peneliti melakukan penelitian dengan judul, "Perbedaan Pengaruh Gaya Mengajar Komando dengan Gaya Mengajar Latihan Terhadap Minat Peserta Didik pada Pembelajaran Teknik Dasar Permainan Bolavoli di Kelas X MAN Kota Batu.

Berdasarkan penelitian terdahulu oleh Raharjo, 2010 Fakultas Keguruan dan Ilmu Pendidikan, Universitas Sebelas Maret Surakarta yang berjudul "perbedaan kesesuaian gaya mengajar komando dan gaya mengajar resiprokal terhadap kemampuan shooting bolabasket pada siswa putra kelas VIII SMP Negeri 2 Jatiroto Kabupaten Wonogiri tahun 2010". Dari hasil uji t yang dilakukan maka dapat disimpulkan ada perbedaan kesesuaian gaya mengajar komando dan gaya mengajar resiprokal terhadap kemampuan shooting bolabasket pada siswa putra kelas VIII SMP Negeri 2 Jatiroto Kabupaten Wonogiri tahun 2010, karena nilai $t_{\text {hitung }}$ yang diperoleh sebesar 2,57 , lebih besar dari $t_{\text {tabel }}$ sebesar 2,010.

Tujuan penelitian ini adalah untuk mengetahui dan mengkaji pengaruh gaya mengajar komando terhadap minat peserta didik pada pembelajaran teknik dasar permainan bolavoli di kelas X MAN Kota Batu. Untuk mengetahui dan mengkaji pengaruh gaya mengajar latihan terhadap minat peserta didik pada pembelajaran teknik dasar permainan bolavoli di kelas X MAN Kota Batu. Untuk mengetahui dan mengkaji perbedaan pengaruh gaya mengajar komando dengan gaya mengajar latihan terhadap minat peserta didik pada pembelajaran teknik dasar 
permainan bolavoli di kelas X MAN Kota Batu.

\section{METODE}

Rancangan penelitian yang digunakan dalam penelitian ini adalah rancangan eksperimen sungguhan (true experimental) bentuk rancangan two group pretest posttest design dengan pemilihan kelompok secara acak. Ditinjau dari tujuan penelitian ini, maka penelitian tentang perbedaan pengaruh gaya mengajar komando dan gaya mengajar latihan terhadap minat belajar peserta didik ini termasuk jenis penelitian eksperimen sungguhan.

Variabel yang diteliti berupa (1) variabel bebas yang dimanipulasikan adalah (a) gaya mengajar komando dan (b) gaya mengajar latihan sedangkan untuk variabel terikatnya adalah minat belajar peserta didik. Disamping itu perlu adanya kelompok pembanding (kontrol), dan perlakuan dilakukan secara berulang-ulang. Langkah-langkah yang diterapkan peneliti sebagai berikut: (1) Menentukan kelompok eksperimen teknik pemilihan kelompok secara acak. (2) Penyebaran angket pertama untuk diisi oleh siswa disebut tes awal. (3) Memberikan perlakuan pembelajaran menggunakan gaya mengajar komando bagi kelompok eksperimen A dan gaya mengajar latihan bagi kelompok experimen B selama 6 kali pertemuan dan setiap minggunya sebanyak 1 kali untuk masing-masing kelompok. (4) Penyebaran angket kedua diisi oleh siswa (setelah diberi perlakuan) yang disebut tes akhir.

Populasi dalam penelitian ini adalah peserta didik kelas X MAN Kota Batu. Kelas X di sekolah MAN Kota Batu ini memiliki 372 peserta didik yang terbagi atas 11 kelas. Teknik pengambilan sampel dilakukan dengan menggunakan simple random sampling yaitu teknik pengambilan sampel secara acak sederhana. Dari populasi 11 kelas diambil 2 kelas untuk sampel. Pada penelitan ini semua kelas dianggap sama dan memiliki hak yang sama yaitu mendapat kesempatan untuk dipilih menjadi sampel. Cara pengambilan sampel dilakukan dengan lotre atau acak yaitu: (1) Perwakilan anak dari 11 kelas diminta berkumpul. (2) Setiap perwakilan kelas diberi nomor undian. Kelas X 1 mendapat undian nomor 1 lalu kelas X 2 mendapat undian nomor 2 dan seterusnya. (3) Nomor undian ditulis dikertas kecil dan digulung. (4) Gulungan kertas dimasukan ke dalam kaleng. (5)Memulai pengundian (6) Kertas undian yang jatuh pertama dilakukan kelompok eksperimen 1. (7) dan yang kedua kelompok experimen 2. Sampel penelitian dibagi menjadi 2 kelas, pembagian dilakukan menggunakan teknik acak. Tiap kelompok terdiri dari 28 orang. Pembagian kelompok tersebut yaitu kelompok kelas gaya mengajar komando dan kelompok kelas gaya mengajar latihan.

Instrumen yang digunakan berupa instrumen non tes bentuk angket dan observasi untuk mengetahui minat belajar peserta didik. Adapun beberapa inetrumen pendukung berlangsungnya penelitian yaitu: (1) Rencana pelakasanaan pembelajaran gaya mengajar komando digunakan sebagai acuan berlangsungnya pembelajaran. (2) Lembar observasi untuk mengetahui proses belajar mengajar gaya mengajar komando. Pengamat memperhatikan perubahan minat peserta didik saat pembelajaran berlangsung. (3) Rencana pelaksanaan pembelajaran gaya mengajar latihan digunakan sebagai acuan berlangsungnya pembelajaran. (4) Kertas tugas yang telah dirancang oleh peneliti sebagai acuan peserta didik saat melaksanakan pembelajaran pada tahap impact. (5) Lembar observasi untuk mengetahui proses belajar mengajar gaya mengajar latihan. Pengamat memperhatikan perubahan minat peserta didik saat pembelajaran berlangsung. (6) Lembar angket untuk mengetahui minat peserta didik yang dibagikan pada awal dan akhir penelitian.

Teknik pengumpulan data yang digunakan dalam penelitian ini berupa eksperimen, angket dan observasi. Beberapa tahapan yang harus dilakukan dalam pengumpulan data adalah sebagai berikut: (1). Orientasi sampel penelitian yaitu dua kelompok penelitian mengunakan teknik acak sederhana untuk dijadikan sebagai kelompok gaya mengajar komando dan kelompok gaya mengajar latihan. (2) Pengisian angket minat peserta didik pada pembelajaran teknik dasar permainan bolavoli yaitu pengambilan data tes awal sebelum diberikan perlakuan pembelajaran menggunakan gaya mengajar komando dan gaya mengajar latihan. (3) Perlakuan yaitu subjek diberikan perlakuan berupa pembelajaran teknik dasar permainan bolavoli dengan gaya mengajar komando untuk kelompok $\mathrm{A}$ dan gaya mengajar latihan untuk kelompok B. (4) Pengisian angket minat peserta didik pada pembelajaran teknik dasar bolavoli yaitu pengambilan data tes akhir setelah diberikan perlakuan pembelajaran menggunakan gaya mengajar komando dan gaya mengajar latihan.

Berdasarkan tujuan penelitian yang telah dirumuskan teknik analisis data dalam penelitian ini menggunakan analsisis deskriptif 
dan analisis varian satu arah. Teknik analisis varian satu arah yaitu untuk menguji perbedaan rata-rata minat belajar pada dua distribusi atau lebih dengan taraf signifaksi $\alpha=0.05$. "Alat ini dipakai untuk menetukan apakah nilai tengah dari tiga atau lebih distribusi nilai kelompok berbeda satu sama lain secara nyata" (Adriani, 2012:6.17).

Sebelum dilakukan analisis varian satu arah maka terlebih dahulu dilakukan uji prasyarat berupa uji normalitas dan uji homogenitas. Uji normalitas data menggunakan teknik Komolgorof Smirnof dengan taraf signifikasi $\alpha=0.05$. Uji homogenitas data menggunakan uji Statistic Levene dengan taraf signifikasi $\alpha=0.05$. Pengujian hipotesis menggunakan taraf signifikansi 5\% $(\alpha=0,05)$.

\section{HASIL}

Hasil penelitian minat peserta didik pada pembelajaran permainan bolavoli diperoleh dari jawaban peserta didik kelas X.6 sebagai kelompok gaya mengajar latihan dan X.11 sebagai kelompok gaya mengajar komando MAN Kota Batu sebagai subjek penelitian terhadap instrumen pengumpulan data yang berupa kuesioner. Data yang terkumpul bertujuan untuk mengetahui apakah terdapat pengaruh pada gaya mengajar komando dan gaya mengajar latihan terhadap minat peserta didik. Juga untuk mengetahui perbedaan pengaruh antara kedua gaya mengajar tersebut terhadap minat belajar peserta didik.

Dari hasil perhitungan menggunakan SPSS dinyatakan bahwa nilai perhitungan dengan uji Kolmogorov Smirnov tes awal minat belajar untuk kelompok gaya mengajar komando adalah sebesar 0,887 nilai tersebut lebih besar dari 0,05. Maka dapat disimpulkan data tes awal belajar peserta didik pada gaya mengajar komando memiliki data yang normal.

Dari hasil perhitungan menggunakan SPSS dinyatakan bahwa nilai perhitungan dengan uji kolmogorov smirnov tes awal minat belajar untuk kelompok gaya mengajar latihan adalah sebesar 0,587 nilai tersebut lebih besar dari 0,05. Maka dapat disimpulkan data tes awal minat belajar peserta didik pada gaya mengajar latihan memiliki data yang normal.

Dari hasil perhitungan dinyatakan bahwa nilai perhitungan dengan uji levene's two group pretest-posttest menggunakan SPSS sebesar .053 nilai ini lebih besar dari 0,05,maka dapat disimpulkan data tes awal dan tes akhir minat belajar peserta didik pada gaya komando memiliki data yang homogen.
Dari hasil perhitungan dinyatakan bahwa nilai perhitungan dengan uji levene's two group pretest-posttest menggunakan SPSS sebesar 0.057 nilai ini lebih besar dari 0,05 , maka dapat disimpulkan data tes awal dan tes akhir minat belajar peserta didik gaya latihan memiliki data yang homogen.

Dari hasil perhitungan dinyatakan bahwa nilai perhitungan dengan uji levene's two group pretest-posttest menggunakan SPSS sebesar 0,536 nilai ini lebih besar dari 0,05,maka dapat disimpulkan data tes akhir minat belajar peserta didik pada gaya komando dan latihan memiliki data yang homogen.

Pada gaya mengajar komando hasil analisis varian satu arah dengan temuan Sig .000 yang menunjukan $<\alpha=0,05$ maka Ho ditolak atau $\mathrm{Ha}$ diterima. Maka terdapat perbedaan rata-rata nilai minat belajar peserta didik pada pembelajaran permainan bolavoli. Rata-rata minat belajar tes akhir lebih besar dibandingkan rata-rata minat belajar tes awal dengan demikian dapat disimpulkan terdapat pengaruh pada gaya mengajar komando terhadap minat peserta didik dalam pembelajaran permainan bolavoli.

Pada gaya mengajar latihan analsis varian satu arah dengan temuan Sig .000 yang menunjukan $<\alpha=0,05$ maka Ho ditolak atau Ha diterima. Maka terdapat perbedaan rata-rata nilai minat belajar peserta didik pada pembelajaran permainan bolavoli. Rata-rata minat belajar tes akhir lebih besar dibandingkan rata-rata minat belajar tes awal dengan demikian dapat disimpulkan terdapat pengaruh pada gaya mengajar latihan terhadap minat peserta didik dalam pembelajaran permainan bolavoli.

Untuk mengetahui perbedaan pengaruh maka diuji hasil tes akhir gaya mengajar komando dan tes akhir gaya mengajar latihan. Dari hasil analsis varian satu arah Sig .000 yang menunjukan $<\alpha=0,05$ maka Ho ditolak atau $\mathrm{Ha}$ diterima. Maka terdapat perbedaan rata-rata hasil tes akhir nilai minat belajar peserta didik dengan gaya mengajar komando dan gaya mengajar latihan pada pembelajaran permainan bolavoli. Rata-rata minat belajar hasil tes akhir gaya mengajar latihan $(127,39)$ lebih besar dibandingkan ratarata minat belajar tes akhir gaya mengajar komando $(119,03)$. Dengan demikian dapat disimpulkan gaya mengajar latihan lebih berpengaruh secara signifikansi dari pada gaya mengajar komando dalam menumbuhkan minat peserta didik pada pembelajaran permainan bolavoli. 


\section{PEMBAHASAN}

Pada gaya mengajar komando dilihat berdasarkan dari hasil temuan perhitungan tes awal dan tes akhir minat belajar peserta didik diperoleh nilai Sig 0,000 < 0,05. Berdasarkan temuan tersebut hipotesis nihil (Ho) ditolak, yang menyatakan tidak ada perbedaan minat belajar peserta didik tes awal dan tes akhir pada kelompok gaya mengajar komando dengan taraf signikansi $\alpha=0,05$ sehingga hipotesis alternative $(\mathrm{Ha})$ diterima.

Atas dasar temuan tersebut juga dapat disimpulkan gaya mengajar komando berpengaruh signifikan terhadap minat belajar peserta didik. Minat belajar peserta didik pada tes akhir lebih baik dari tes awal.

Setelah menerapkan gaya mengajar komando selama enam minggu dengan rincian satu kali dalam seminggu secara disiplin dan sesuai dengan Rencana Pelaksanaan Pembelajaran (RPP), maka gaya mengajar ini akan berpengaruh terhadap perkembangan minat peserta didik dalam pembelajaran. "Minat belajar merupakan suatu kegiatan yang dilakukan oleh siswa secara tetap-dalam melakukan proses belajar" (Siagian, 2010:123). Hurlock (1980:168) menjelaskan bahwa "sikap anak sangat dipengaruhi oleh menarik atau tidaknya cara guru menyajikan bahan yang harus dipelajari". Indikator yang muncul adalah perhatian peserta didik pada pembelajaran, ketertarikan untuk melakukan gerakan, muncul keinginan dalam mengikuti tahaptahap pembelajaran yang diterapkan guru. Menurut Slameto (2010:57) dalam bukunya belajar dan faktor-faktor yang mempengaruhinya menjelaskan "bahwa minat besar pengaruhnya terhadap belajar, karena bila bahan pelajaran tidak sesuai dengan minat siswa, siswa tidak akan belajar dengan sebaikbaiknya, karena tidak ada daya tarik baginya". Hal tersebut sudah sesuai dengan gaya mengajar komando yang diterapkan.

Pada gaya mengajar latihan dilihat berdasarkan dari hasil temuan perhitungan tes awal dan tes akhir minat belajar peserta didik diperoleh nilai Sig $0,000<0,05$. Berdasarkan temuan tersebut hipotesis nihil (Ho) ditolak, yang menyatakan tidak ada perbedaan minat belajar peserta didik tes awal dan tes akhir pada kelompok gaya mengajar komando dengan taraf signikansi $\alpha=0,05$ sehingga hipotesis alternative $(\mathrm{Ha})$ diterima.
Atas dasar temuan tersebut juga dapat disimpulkan gaya mengajar komando berpengaruh terhadap minat belajar peserta didik. Melihat nilai rata-rata skor minat belajar peserta didik untuk tes awal 67,46 dan tes akhir 127,39, maka dapat disimpulkan minat belajar peserta didik pada tes akhir lebih baik dari tes awal.

Dari penelitian yang telah dilaksanakan setelah menerapkan gaya mengajar latihan selama enam minggu dengan rincian satu kali dalam seminggu secara disiplin dan sesuai dengan Rencana Pelaksanaan Pembelajaran (RPP), maka gaya mengajar ini berpengaruh terhadap perkembangan minat peserta didik dalam pembelajaran. Mursid (2012:2) menjelaskan "minat belajar adalah ketertarikan dari diri siswa dalam proses belajar mengajar sebagai wujud kemauan untuk melaksanakan suatu kegiatan belajar dengan ciri timbulnya perasaan senang". Hurlock (1980:217) menjelaskan bahwa "minat yang dibawa dari masa kanak-kanak cenderung berkurang dan di gantikan oleh minat yang lebih matang karena tanggung jawab yang lebih besar". Indikator yang muncul adalah perhatian peserta didik pada pembelajaran, ketertarikan untuk melakukan gerakan, muncul keinginan dalam mengikuti tahap-tahap pembelajaran yang telah tersusun dikertas tugas. Menurut Slameto (2010:180) dalam bukunya belajar dan faktorfaktor yang mempengaruhinya menjelaskan "bahwa minat/dapat/diekspresikan melalui suatu pernyataan yang menunjukan bahwa siswa lebih menyukai suatu hal dari pada hal lainya, dapat pula dimanifestasikan melalui partisipasi dalam suatu aktifitas ". Hal tersebut sudah sesuai dengan gaya mengajar komando yang diterapkan.

Setelah penelitian yang dilakukan selama enam minggu dengan rincian pembelajaran satu kali dalam seminggu yang sesuai dengan RPP. Dari kedua gaya mengajar yang diterapkan yaitu gaya mengajar komando dan gaya mengajar latihan keduanya sama-sama memberikan pengaruh pada minat belajar peserta didik.

Peneliti menemukan kedua kelompok ini sama-sama melakukan kegiatan pembelajaran yang diterapkan di kelas. Saat pembelajaran berlangsung perbedaan dari gaya mengajar ini terdapat pada tahap inti pembelajaran. Melihat rata-rata skor hasil penilaian tes akhir minat kelompok gaya mengajar latihan adalah 127,39 dan kelompok gaya mengajar komando 119,03. Skor hasil penilaian rata-rata tes akhir diperoleh dari penjumlahan seluruh skor hasil penilaian minat masing-masing kelompok 
dibagi banyaknya subjek. Dapat disimpulkan kelompok gaya mengajar latihan lebih baik daripada kelompok gaya mengajar komando untuk menumbuhkan minat belajar peserta didik.

Gaya mengajar komando memiliki pengaruh yang sgnifikan terhadap minat belajar peserta didik. Karena gaya mengajar ini terfokus pada kinerja guru pendidikan jasmani dalam menyusun pembelajaran yang menarik. Tetapi gaya mengajar latihan memiliki hasil perhitungan yang lebih signifikan dibandingkan gaya mengajar komando. Itu berarti gaya mengajar latihan lebih berpengaruh terhadap minat belajar peserta didik dibandingkan gaya mengajar komando pada pembelajaran permainan bolavoli.

\section{KESIMPULAN}

Berdasarkan hasil penelitian dan pembahasan, maka ini dapat disimpulkan sebgai berikut:

1. Gaya mengajar komando berpengaruh secara signifikan terhadap minat peserta didik pada pembelajaran permainan bolavoli.

2. Gaya mengajar latihan berpengaruh secara signifikan terhadap minat peserta didik pada materi pembelajaran permainan bolavoli.

3. Terdapat perbedaan pengaruh antara gaya mengajar komando dan gaya mengajar latihan. Maka dapat disimpulkan gaya mengajar latihan lebih berpengaruh secara signifikansi dibandingkan gaya mengajar komando terhadap minat peserta didik pada pembelajaran permainan bolavoli kelas X MAN Kota Batu

\section{DAFTAR PUSTAKA}

Ahmadi,2007. Panduan Olahraga Bola Voli. Surakarata. ERA PUSTAKA UTAMA.

Andriani, (dkk). 2012. Metodologi Penelitian. Tangerang Selatan. Universitas Terbuka Kementrian Pendidikan dan Kebudayaan.

Anggraini. 2014. Pengembangan Teknik Dasar service Bawah Bolavoli untuk siswa kelas VIII SMP Negeri 5 Malang. Jurnal Pendidikan. 1 (1) : 81-87
Arisandi. 2009. Pelaksanaan Pembelajaran Pendidikan Jasmani Dan Kesehatan Bagi Anak Ceberal Palsy Kelas V.d di SLB YPPLB Padang. Jurnal Ilmiah Pendidikan Kusus,(online). 3 (3) : 1326,(http//ejournal.unp.ac.id/index.ph p/jupekhu.)

Durrwachter. 1986. Bola Volley Belajar dan Berlatih Sambil Bermain. Jakarata. PT Gramedia.

Giriwoyo (dkk). 2005. Manusia Dan Olahraga. Bandung. ITB.

Hurlock B.1980. Psikologi Perkembangan Suatu Pendekatan Sepanjang Rentang Kehidupan. Jakarta. Penerbit Erlangga.

Husdarta JS., Saputra Y M. 2013. Belajar dan Pembelajaran Pendidikan Jasmani dan Kesehatan. Bandung: Alfabeta.

Husdarta, JS. 2011. Sejarah dan Filsafat Olahraga. Bandung. Alfabeta

Kleinman D. 1982. Bola Volley Pembinaan teknik, taktik dan kondisi. Jakarata. PT Gramedia.

Mooston. Tanpa Tahun. Gaya Mengajar Pendidikan Jasmani. Terjemahan Asim. 2013. Malang: Wineka Media.

Mursid. 2012. Perbedaan Minat Dan Prestasi Belajar Siswa Pada Mata Diklat Mengoprasikan/Sistem Kendali Elektronik Dengan Menggunakan Software Tutorial PLC siswa kelas XI SMAK Negeri 2 Pengasih. Jurnal Skripsi.

Nazir, Moh. 2014. Metode Penelitian. Ghalia Indonesia. Bogor.

Nuruddin P, 2010. Strategi Pembelajaran Pendidikan Jasmani. Jurnal ilmiah SPIRIT.ISSN. 10 (2): 11-25.

Paturisi. 2012. Manajamen Pendidikan Jasamani Dan Olahraga. Jakarta. PT RINEKA CIPTA

Rosdiani. 2013. Perencanaan pembelajaran dalam pendidikan jasmani dan kesehatan. Bandung. Alfabeta.

Rukmana, Amin. 2008. Pembelajaran pendidikan jasmani Di Sekolah dasar. Jurnal pendidikan Jasmani. (9) : 1-9.

Siagian. 2010. Pengaruh Minat Dan Kebiasaan Belajar Siswa Terhadap Prestasi Belajar Matematika. Jurnal Formatif 2(2): 122131. 
Slameto. 2010. Belajar dan Faktor-Faktor yang Mempengaruhi. PT RINEKA CIPTA.

Jakarta.

Sudarsini. 2013. Pendidikan Jasmani Dan Olahraga. Malang. Fakultas Ilmu Pendidikan Universitas Negeri Malang.

Suhadi. 2005. Pengaruh Model Pembelajaran Bola Voli Suhadi Terhadap Kemampuan Kognitif Anak Sekolah Dasar .Jurnal Pendidikan Jasmani Indonesia .1 (3) 112.

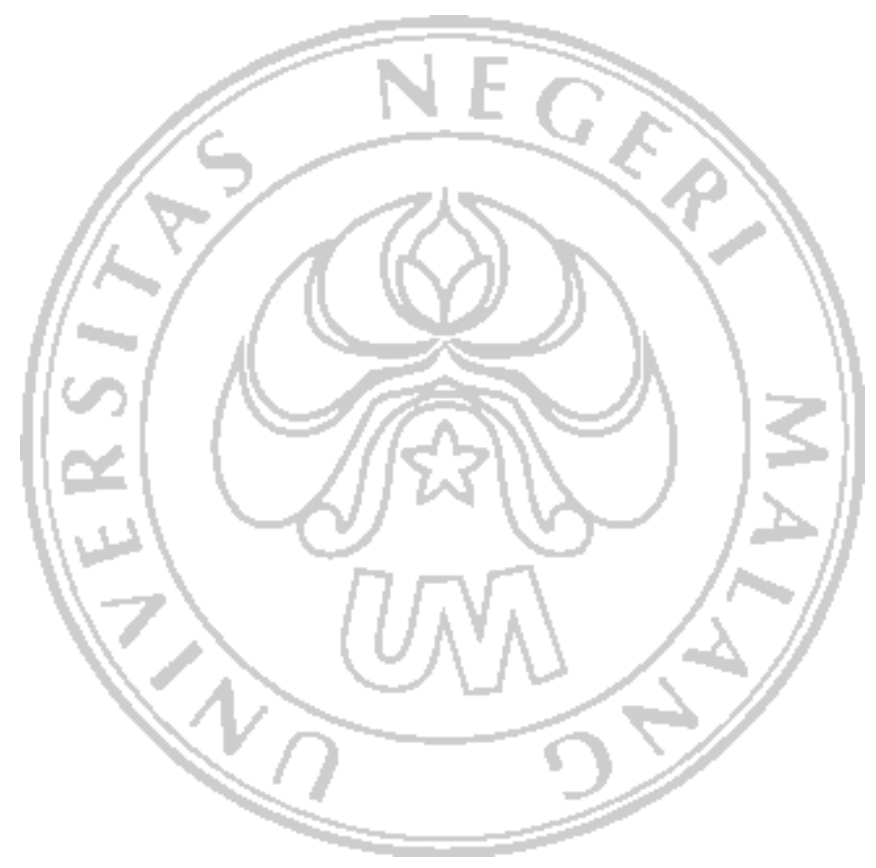

